\title{
The CD45 77C/G allele is not associated with myasthenia gravis - a reassessment of the potential role of CD45 in autoimmunity
}

\author{
Ryan Ramanujam', Ritva Pirskanen², Lennart Hammarström ${ }^{1 *}$
}

\begin{abstract}
Background: The G allele of the CD45 77C/G SNP (rs17612648), which has previously been suggested to be associated with autoimmune disorders, was genotyped in 446 Swedish myasthenia gravis (MG) patients and 2303 matched controls.

Results: There was no association between the polymorphism and patient group as a whole $(p=0.199)$, nor with clinical subgroups. Our results add to a growing number of studies unable to find association between the $77 \mathrm{C} / \mathrm{G}$ polymorphism and autoimmune disorders. One control sample, from an adult blood donor, was homozygous for the $\mathrm{G}$ allele, yet negative for a panel of auto-antibodies, representing the first homozygous individual studied in this respect.
\end{abstract}

Conclusions: The 77C/G mutation does not predispose to $M G$, and its role in autoimmunity may have to be re-evaluated.

\section{Background}

Myasthenia gravis (MG) is an autoimmune disorder characterized by the presence of antibodies against the nicotine acetylcholine receptor on the muscle end-plate, thereby impairing transmission of nerve impulses to the muscle. MG occurs in 14/100,000 individuals in Sweden and patients commonly display thymic abnormalities such as thymoma and hyperplasia, where the former usually is associated with a severe disease [1]. Polymorphisms in several "classical" autoimmune genes have previously been shown to be associated with myasthenia gravis, including $I L-1, P T P N 22$ and TNF- $\alpha$ [2]. Furthermore, an association has also been observed with the HLA haplotype A1, B8, DR3 [3-5], known to be linked to several "autoimmune" disorders [6-8].

CD45 (PTPRC), located on chromosome 1q31-32, is a receptor belonging to the protein tyrosine phosphatase family, consisting of molecules which have been shown to be involved in cell growth, differentiation and

\footnotetext{
* Correspondence: lennart.hammarstrom@ki.se

'Division of Clinical Immunology, Department of Laboratory Medicine, Karolinska Institutet at Karolinska University Hospital Huddinge, SE-141 86 Stockholm, Sweden

Full list of author information is available at the end of the article
}

signaling. The receptor is heavily expressed on T-cells, where it comprises up to $10 \%$ of all surface proteins [9]. It has previously been shown to play a role in $\mathrm{T}$-cell receptor signal transduction and activation as well as in thymic selection of $\mathrm{T}$-cells, both important features in the development of autoimmunity [9], whereas a lack of CD45 expression results in severe immunodeficiency $[10,11]$. It undergoes complex, cell specific, alternative splicing to produce eight known isoforms. One isoform, containing exon 4 (CD45RA+), is expressed mainly by naïve $T$-cells, while an isoform with exons 4-6 spliced out $(\mathrm{CD} 45 \mathrm{RO}+)$ is expressed by most memory $\mathrm{T}$-cells [9]. The $G$ allele of a low frequency single nucleotide polymorphism (SNP), 77C/G (rs17612648), has been reported to disrupt an exonic splicing silencer in exon 4, thereby leading to expression of higher levels of CD45RA on memory T-cells [12]. This, in turn, alters the $\mathrm{T}$-cell activation threshold, providing a possible mechanism for development of autoimmunity [13].

CD45 shares homology and functional features with PTPN22, another protein member of the tyrosine phosphatase family. The latter contains a $1858 \mathrm{C} / \mathrm{T}$ polymorphism (rs2476601) that has been shown to alter the $\mathrm{T}$-cell activation threshold, due to an intracellular 
disruption of binding to the protein Csk [14]. This polymorphism has been strongly associated with many autoimmune disorders, including systemic sclerosis, rheumatoid arthritis (RA), systemic lupus erythematosus (SLE), MG, type I diabetes (TID) and multiple sclerosis (MS) [15-19]. Due to the similar role of CD45 in determining T-cell activation thresholds, a study investigating the association between the $77 \mathrm{C} / \mathrm{G}$ polymorphism and MS was previously performed [20]. An association in three of four investigated populations was reported, thereby triggering a large number of replication studies.

This study was aimed at investigating association of this polymorphism with myasthenia gravis.

\section{Methods}

\section{Patients and controls}

Four hundred and sixty-six Swedish Caucasian MG patients and 2314 ethnically matched controls derived from anonymized adult blood donors $(\mathrm{n}=1594)$ and dried blood spot samples from newborns $(n=720)$ from a population based study [21] were included in the study. The diagnosis of myasthenia gravis was made as described previously [1]. Antibodies against the acetylcholine receptor (AChR) were determined by radioimmunoassay [22], and testing for additional autoantibodies was performed using Bio Rad Bio-plex ANA and ANCA screens at the Karolinska University Hospital Laboratory. Immunoglobulin levels were determined by nephelometry at the Karolinska University Hospital Laboratory. Clinical information was documented by the primary physician over the course of treatment, and informed consent was given at the initial patient visit. Ethical permission was obtained from the Karolinska Institutet for use of patient and control materials.

\section{CD45 genotyping}

Genotyping for the rs17612648 SNP in 466 MG samples and 2314 controls was performed using matrix-assisted laser desorption/ionization time-of-flight (MALDI-TOF) mass spectrometry [23] (SEQUENOM Inc., San Diego, California, USA) at the Mutation Analysis Facility of the Karolinska Institutet, Sweden. All samples that were found to be heterozygous or homozygous for the $\mathrm{G}$ allele were subsequently amplified and subjected to direct sequencing at Macrogen, South Korea, using the primers CTGGGAGGAGCATACATTTAGG and AGCACTAGCATTATCCAAAGAG, in order to verify the result.

\section{Statistical analysis}

The Chi square test was used to compare the allelic frequency of CD45 in patients and controls. For all tests, a $p$-value below 0.05 was considered to indicate statistical significance. Power for the study was calculated using the
"CaTS - Power Calculator for Two Stage Association Studies" http://www.sph.umich.edu/csg/abecasis/CaTS/ [24].

\section{Patient subgrouping}

Due to the complex nature of MG, which may contain several genetically distinct diseases exhibiting similar phenotypes, we stratified the patient material into subgroups based on the available clinical information. Patients were thus separated on the basis of sex, antibody status (anti-AChR positive or negative), thymic status (normal, hyperplasia or thymoma), disease severity (ocular, generalized or severe) as well as by age of onset. In the latter case, patients with age of disease onset less than 40 constituted the early onset group (EOMG), while those with an age of onset 50 or more were assigned to the late onset group (LOMG). Anti-AChR negative patients were defined as those who had never tested positive for anti-AChR antibodies, and had at least one negative test on record. We furthermore investigated possible association with known HLA biases within MG, specifically within the HLA B8, DR3 haplotype (EOMG) and the HLA B7 and DR2 alleles (LOMG) [25]. For each analysis, a Bonferroni correction was applied based on the number of independent subgroups created by the patient stratification.

\section{Results}

Of the 466 genotyped MG samples, 20 were removed due to ambiguous readings, resulting in 446 appropriately typed samples. The number of control samples, after removing 11 samples with unsuccessful genotyping, was 2303.

The genotyping results are given in Table 1. Allelic variants of rs17612648 were not associated with myasthenia gravis in the patient group as a whole $(p=$ $0.199)$, although the minor (G) allele appears slightly more frequently in MG patients than in controls $(1.91 \%$ compared with $1.35 \%$ ). Neither was any subgroup of MG associated with the SNP ( $p>0.260$, corrected), despite a slightly elevated minor allele frequency in most subgroups. Of all the patient subgroups, only the LOMG HLA B7 (0.91\% MAF) and DR2 (0.81\% MAF) subgroups had a lower frequency of the $G$ allele than the control population (1.35\% MAF), although, due to the low allele frequency, each group contained only one heterozygous case.

We furthermore observed a blood donor control sample homozygous for the $\mathrm{G}$ allele, which was confirmed by sequencing (Figure 1). Due to the presumed deleterious effect of homozygosity of this allele [26], a serum sample was tested in order to determine if autoantibodies were present. ANA antibodies (Anti-Nucleosome, Ribosomal P, RNP68, RNP A, Scl-70, Sm, SmRNP, SS-A (Ro52), SS-A(Ro60), SS-B, Centromere, Jo-1 and 
Table 1 Results of CD45 77C/G genotyping in myasthenia gravis patients and subgroups

\begin{tabular}{|c|c|c|c|c|c|c|c|c|c|}
\hline MG patients & n & G & C & MAF & $p$-val uncorrected & $p$-val corrected & OR & $95 \%$ confidence interval for OR & Power $(\%)^{b}$ \\
\hline All patients & 446 & 17 & 875 & 0.019 & 0.199 & - & 1.42 & $0.83-2.45$ & $>99$ \\
\hline Female & 268 & 9 & 527 & 0.017 & 0.532 & 1.000 & 1.25 & $0.62-2.53$ & $>99$ \\
\hline Male & 175 & 8 & 342 & 0.023 & 0.151 & 0.302 & 1.71 & $0.81-3.61$ & 96 \\
\hline EOMG $^{\mathrm{a}}$ (age of onset $\leq 40$ ) & 208 & 9 & 407 & 0.022 & 0.176 & 0.352 & 1.62 & $0.80-3.28$ & 98 \\
\hline LOMG $^{a}$ (age of onset $>50$ ) & 179 & 5 & 353 & 0.014 & 0.936 & 1.000 & 1.04 & $0.41-2.60$ & 96 \\
\hline Hyperplasia & 161 & 6 & 316 & 0.019 & 0.442 & 1.000 & 1.39 & $0.60-3.24$ & 93 \\
\hline Thymoma & 54 & 3 & 105 & 0.028 & 0.207 & 0.621 & 2.09 & $0.65-6.78$ & $<70$ \\
\hline Normal Thymus & 60 & 2 & 118 & 0.017 & 0.764 & 1.000 & 1.24 & $0.30-5.14$ & $<70$ \\
\hline Ocular & 42 & 1 & 83 & 0.012 & 0.902 & 1.000 & 0.88 & $0.12-6.44$ & $<70$ \\
\hline Generalized & 289 & 13 & 565 & 0.022 & 0.087 & 0.260 & 1.69 & 0.92-3.09 & $>99$ \\
\hline Severe disease & 114 & 3 & 225 & 0.013 & 0.969 & 1.000 & 0.98 & $0.34-3.14$ & 79 \\
\hline Anti-AChR ab. negative & 54 & 3 & 105 & 0.028 & 0.207 & 0.414 & 2.09 & $0.65-6.78$ & $<70$ \\
\hline Anti-AChR ab. positive & 389 & 14 & 764 & 0.018 & 0.321 & 0.642 & 1.34 & $0.75-2.41$ & $>99$ \\
\hline HLA B8, DR3 (EOMG) & 85 & 3 & 167 & 0.018 & 0.644 & 1.000 & 1.32 & $0.41-4.24$ & $<70$ \\
\hline HLA-B7 (LOMG) & 55 & 1 & 109 & 0.009 & 0.693 & 1.000 & 0.67 & $0.09-4.89$ & $<70$ \\
\hline HLA-DR2 (LOMG) & 62 & 1 & 123 & 0.008 & 0.605 & 1.000 & 0.60 & $0.08-4.33$ & $<70$ \\
\hline Controls & 2303 & 62 & 4544 & 0.013 & & & & & \\
\hline
\end{tabular}

Allele frequencies for patients and subgroups are given as well as uncorrected and corrected $p$-values of the $77 \mathrm{C} / \mathrm{G}$ polymorphism association with the disease. A Bonferroni correction was applied to subgroups based on the number of independent samples in each.

${ }^{a}$ EOMG and LOMG patients were anti-AChR antibody positive without the presence of thymoma

b The power of each group/subgroup comparison to detect the minimum allelic OR (4.53) from all studies reporting a significant association of the SNP to a disorder (Vogel, et. al., 2003, Table 2), at a significance level of 0.05 .

dsDNA) and ANCA antibodies (Anti-PR3, MPO and GBM) could, however, not be demonstrated. Serum immunoglobulin levels were also normal $(\operatorname{IgM}=0.7 \mathrm{~g} / \mathrm{l}$, $\operatorname{IgG}=9.7 \mathrm{~g} / \mathrm{l}, \operatorname{IgA}=1.7 \mathrm{~g} / \mathrm{l})$. Due to restrictions in the ethical permission of the study, requesting anonymous control samples, material for additional analysis, including CD45 expression, could not be obtained.

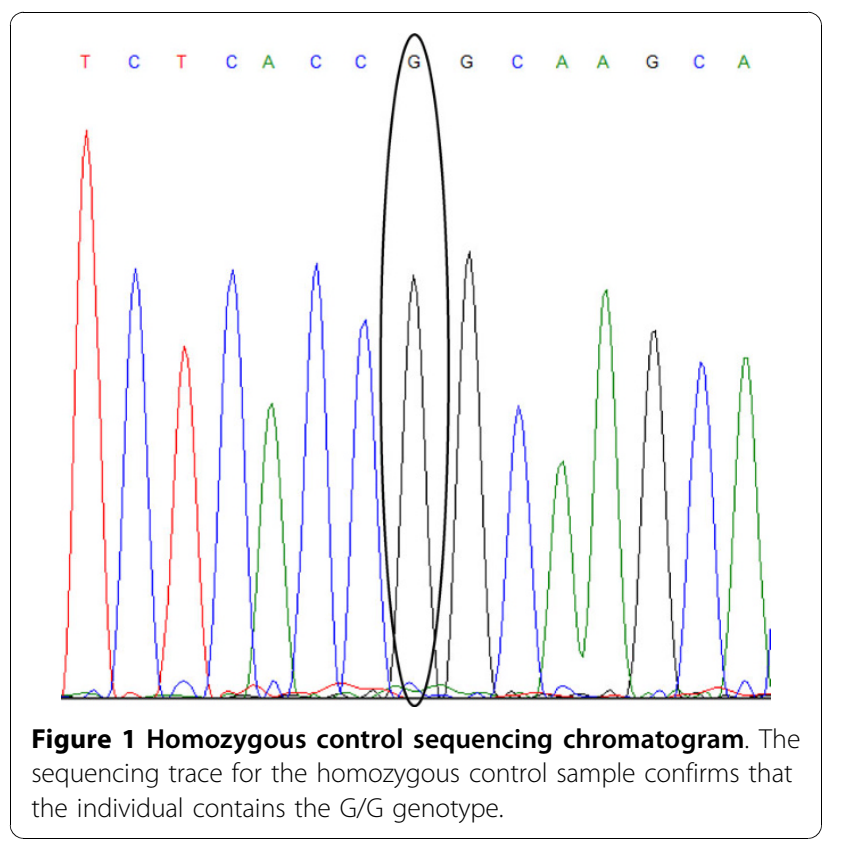

\section{Discussion}

The $G$ allele of the CD45 $77 \mathrm{C} / \mathrm{G}$ polymorphism (rs17612648) was previously reported to be associated with MS in multiple patient cohorts, sparking interest in a possible common disease mechanism in related disorders. Table 2 presents an overview of the results of studies on CD45 77C/G association with autoimmunity to date. The compiled minor allele $(G)$ frequency from these studies is approximately $1 \%$; using this figure, our study has $80 \%$ power to detect allelic odds ratios greater than 2.5 , far more sensitive than any study published to date which has reported significant association of the polymorphism to autoimmunity (Table 2).

In nine follow up studies on association of the SNP with MS, only two have reported a significant association $(p=0.02$ and $p=0.0342)[27,28]$. In the latter study, the G allele was observed in 7 of 176 families and the pedigrees of these families were subsequently examined. Significance $(p=0.0342)$ was obtained after the pedigree disequilibrium test failed to give a significant result, after which 10,000 bootstrap samples simulated in the software TRANSMIT approximated significance tests instead of a $\chi^{2}$ test. The lack of an accepted statistical approach, as well as an apparent MAF in cases (1.0-1.5\%) similar to that in the Caucasian population (1-2\%) [29], makes the results questionable. The lack of replication in MS is notable since the original study found an association in three out of four independent populations. An early meta-analysis of the first eight data sets determined that 
Table 2 An overview of published findings investigating association of the 77C/G polymorphism with autoimmune disorders

\begin{tabular}{|c|c|c|c|c|c|c|c|c|}
\hline Study & Year & Population & Disease & $\begin{array}{c}\text { Patients } \\
\operatorname{MAF}(\%)(n)\end{array}$ & $\begin{array}{l}\text { Controls } \\
\operatorname{MAF}(\%)(n)\end{array}$ & OR & $\begin{array}{l}95 \% \text { confidence } \\
\text { interval for OR }\end{array}$ & Association \\
\hline Jacobsen et. al. [20] & 2000 & Germany & MS & 3.2 (219) & 0.0 (189) & $\mathrm{NA}^{+}$ & $\mathrm{NA}^{+}$ & $1.5 \times 10^{-4}$ \\
\hline Jacobsen et. al. [20] & 2000 & Germany & MS & $3.2(108)$ & $0.0(114)$ & $\mathrm{NA}^{\dagger}$ & $N A^{+}$ & 0.0058 \\
\hline Jacobsen et. al. [20] & 2000 & USA & MS & $1.6(122)$ & $1.8(244)$ & 0.89 & $0.27-2.91$ & Not significant \\
\hline Jacobsen et. al. [20] & 2000 & Germany & MS & $3.3(76)$ & $0.4(119)$ & 8.06 & $0.93-69.68$ & 0.0342 \\
\hline Barcellos et. al. [37] & 2001 & USA & MS & $1.7(450)$ & $1.2(253)$ & 1.41 & $0.54-3.66$ & Not significant \\
\hline Vorechovsky et. al. [38] & 2001 & Sweden & MS & $1.5(630)$ & $1.4(1044)$ & 1.05 & $0.59-1.87$ & Not significant \\
\hline Vorechovsky et. al. [38] & 2001 & Sweden & CVID & $2.3(44)$ & $1.4(1044)$ & 1.60 & $0.38-6.78$ & Not significant \\
\hline Vorechovsky et. al. [38] & 2001 & Sweden & $\lg A D$ & $1.4(148)$ & $1.4(1044)$ & 0.94 & $0.33-2.69$ & Not significant \\
\hline Vorechovsky et. al. [38] & 2001 & UK & CVID & $1.5(98)$ & $0.9(232)$ & 1.79 & $0.40-8.06$ & Not significant \\
\hline Vorechovsky et. al. [38] & 2001 & UK & $\lg A D$ & $0.0(17)$ & $0.9(232)$ & $\mathrm{NA}^{\dagger}$ & $N A^{+}$ & Not significant \\
\hline Miterski et. al. [39] & 2002 & Germany & MS & $0.8(454)$ & $1.4(347)$ & 0.53 & $0.20-1.40$ & Not significant \\
\hline Wood et. al. [40] & 2002 & Germany & $\mathrm{TID}$ & $0.2(228)$ & $1.3(196)$ & 0.17 & $0.02-1.46$ & Not significant \\
\hline Wood et. al. [40] & 2002 & Germany & Graves & $1.3(297)$ & $1.3(196)$ & 1.06 & $0.34-3.25$ & Not significant \\
\hline Ballerini et. al.[27] & 2002 & Italy & MS & $1.0(194)$ & $0.0(222)$ & $\mathrm{NA}^{\dagger}$ & $\mathrm{NA}^{\dagger}$ & $p=0.02$ \\
\hline Gomez-Lira et. al. [30] & 2003 & Italy & MS & $1.2(448)$ & $0.9(529)$ & 1.30 & $0.55-3.08$ & Not significant \\
\hline Schwinzer et. al. [31] & 2003 & Germany & $\mathrm{SSC}^{\mathrm{a}}$ & $3.7(67)$ & $0.7(205)$ & 5.26 & $1.24-22.31$ & $p=0.029$ \\
\hline Schwinzer et. al. [31] & 2003 & Germany & SLE & $2.0(98)$ & $0.7(205)$ & 2.83 & $0.63-12.75$ & Not significant \\
\hline Vogel et. al. [32] & 2003 & Germany & $A l H^{b}$ & $3.2(190)$ & $0.7(210)$ & 4.53 & $1.27-16.19$ & $p=0.015$ \\
\hline Tackenberg et. al. [35] & 2003 & Germany & MG & $0.6(78)$ & $0.0(303)$ & $\mathrm{NA}^{\dagger}$ & $N A^{+}$ & Not significant \\
\hline Nicholas et. al. [41] & 2003 & UK & MS & $2.6(330)$ & $2.0(197)$ & 1.28 & $0.55-2.98$ & Not significant \\
\hline Thude et. al. [42] & 2004 & Germany & $\mathrm{TID}$ & $1.2(165)$ & $1.1(220)$ & 1.07 & $0.28-4.01$ & Not significant \\
\hline Cocco et. al.[43] & 2004 & Sardinia & MS & $1.0(246)$ & $0.7(226)$ & 1.54 & $0.37-6-47$ & Not significant \\
\hline Vyshkina et. al. [28] & 2004 & USA & MS & $N A(176)^{c}$ & $N A(N A)$ & NA & NA & $p=0.0342^{d}$ \\
\hline Esteghamat et. al. [44] & 2005 & Iran & $A l H^{b}$ & $0.0(70)$ & $0.4(140)$ & $\mathrm{NA}^{\dagger}$ & $N A^{+}$ & Not significant \\
\hline Kirsten et. al. [45] & 2008 & Germany & $\mathrm{SSC}^{\mathrm{a}}$ & $0.6(171)$ & $1.4(179)$ & 0.42 & $0.08-2.16$ & Not significant \\
\hline Pan-Hammarström et. al.[46] & 2008 & Sweden & $\lg A D$ & $1.3(232)$ & $1.2(913)$ & 1.07 & $0.43-2.66$ & Not significant \\
\hline Pan-Hammarström et. al.[46] & 2008 & Sweden & CVID & $0.5(91)$ & $1.2(913)$ & 0.45 & $0.06-3.38$ & Not significant \\
\hline Szvetko et. al. [34] & 2009 & Australia & MS & $3.2(155)$ & $2.3(171)$ & 2.25 & $0.76-6.65$ & Not significant \\
\hline
\end{tabular}

${ }^{\dagger}$ The OR cannot be calculated for genotypes with some allele count of zero.

${ }^{\text {a }}$ Systemic sclerosis

${ }^{\mathrm{b}}$ Autoimmune hepatitis

' Number of families used to study transmission of $\mathrm{G}$ allele

${ }^{\mathrm{d}}$ Significance determined using 10,000 bootstrap samples in the software TRANSMIT version 2.5 after pedigree disequilibrium test failed to give a significant result

the range of results was due to heterogeneity between different studies $(p=0.01)$, and that exclusion of the first studies of Jacobsen, et. al. would remove heterogeneity $(p=0.23)$, resulting in a lack of association $(p=0.50)$ and an odds ratio of nearly 1 [30]. Of the 15 data sets from studies on other autoimmune disorders, only two have reported positive associations of the SNP to a disorder; systemic sclerosis $(p=0.029)$ [31] and autoimmune hepatitis $(p=0.015)$ [32].

Interestingly, homozygosity was observed in one of our control samples from an adult blood donor. To our knowledge, this is the first reported individual to be confirmed to be homozygous for the mutation. Tchilian et. al. did report a $\mathrm{G}$ homozygous anonymous thymus sample, but the patient was not available for further testing [33]. Svetko, et. al. also reported four G homozygous individuals (two samples in each of the MS and control groups), but did not conduct sequencing to confirm the finding, nor any additional investigations [34]. The overall MAF measured in the latter study (2.76\%) is, however, higher than the aggregate reported for Caucasian samples (1-2\%) [29], which indicates a possible overestimation of the $\mathrm{G}$ allele as does the fact that the genotype counts were not in Hardy Weinberg equilibrium $(p<0.05)$. Our control sample was negative for all tested auto-antibodies, which contradicts the previous assumption that individuals homozygous for the $G$ mutation would be prone to autoimmunity.

A recent study investigated levels of CD45RO and CD45RA cell in German MG patients in which the 
rs17612648 SNP was suggested not to be associated with the disease. However, the number of cases and controls was too low ( $\mathrm{n}=78$ and $\mathrm{n}=303$, respectively) to allow a solid conclusion $(80 \%$ power to detect allelic OR greater than 5.6 at $\alpha=0.05$ ) [35]. In that study, ratios of CD45RO to CD45RA CD8+ T-cells were found to be significantly lower in patients with late onset MG (LOMG) as well as in T-cells in patients with thymoma. These differences suggest an alteration in CD45 expression independent of the rs17612648 SNP, and provide evidence that CD45 splicing may be regulated by other factors. In fact, Zilch et. al. have previously demonstrated that human/mouse somatic cell hybrids carrying only the mutant $(G)$ allele are still able to generate CD45RO [36].

\section{Conclusions}

Our results provide strong evidence for a lack of association of the rs17612648 SNP with MG. Furthermore, the presumed effect of the mutation in autoimmunity is not as strong as initially suggested, as most studies have failed to find an association. It is thus likely that the rs17612648 SNP is not the sole regulator of CD45 isoform expression, and that homozygosity for the mutation may result in neither propensity for autoimmunity, nor an absence of CD45RO expression.

\section{Acknowledgements}

The study was supported by the Palle Ferb Foundation, the Swedish Research Council and a grant (U19AI067152) from the US National Institute of Allergy and Infectious Diseases.

\section{Author details \\ 'Division of Clinical Immunology, Department of Laboratory Medicine, Karolinska Institutet at Karolinska University Hospital Huddinge, SE-141 86 Stockholm, Sweden. ${ }^{2}$ Department of Neurology, Karolinska University Hospital Solna, SE-171 76 Stockholm, Sweden.}

\section{Authors' contributions}

RR performed the statistical analyses, interpreted the results and drafted the manuscript. RP acquired patient material and analyzed clinical data. LH conceived of the experiments, interpreted the results and drafted the manuscript. All authors read and approved the manuscript.

\section{Competing interests}

The authors declare that they have no competing interests.

Received: 24 August 2010 Accepted: 10 November 2010 Published: 10 November 2010

\section{References}

1. Drachman DB: Myasthenia gravis. N Engl J Med 1994, 330:1797-1810.

2. Giraud M, Vandiedonck C, Garchon $\mathrm{H}$ : Genetic factors in autoimmune myasthenia gravis. Ann N Y Acad Sci 2008, 1132:180-192.

3. Pirskanen R, Tiilikainen A, Hokkanen E: Histocompatibility (HL-A) antigens associated with myasthenia gravis. A preliminary report. Ann Clin Res 1972, 4:304-306.

4. Kaakinen A, Pirskanen R, Tiilikainen A: LD antigens associated with HL-A8 and myasthenia gravis. Tissue Antigens 1975, 6:175-182.

5. Giraud M, Beaurain G, Yamamoto AM, Eymard B, Tranchant C, Gajdos P, Garchon HJ: Linkage of HLA to myasthenia gravis and genetic heterogeneity depending on anti-titin antibodies. Neurology 2001, 57:1555-1560.

6. Skarsvåg S, Hansen KE, Holst A, Moen T: Distribution of HLA class II alleles among Scandinavian patients with systemic lupus erythematosus (SLE): an increased risk of SLE among non[DRB1*03,DQA $1 * 0501, \mathrm{DQB} 1 * 0201]$ class II homozygotes? Tissue Antigens 1992, 40:128-133.

7. Volanakis JE, Zhu ZB, Schaffer FM, Macon KJ, Palermos J, Barger BO, Go R, Campbell RD, Schroeder HW, Cooper MD: Major histocompatibility complex class III genes and susceptibility to immunoglobulin A deficiency and common variable immunodeficiency. J Clin Invest 1992, 89:1914-1922.

8. Congia M, Cucca F, Frau F, Lampis R, Melis L, Clemente MG, Cao A, De Virgiliis S: A gene dosage effect of the DQA $1 * 0501 / D Q B 1 * 0201$ allelic combination influences the clinical heterogeneity of celiac disease. Hum Immunol 1994, 40:138-142.

9. Vang T, Miletic AV, Arimura Y, Tautz L, Rickert RC, Mustelin T: Protein tyrosine phosphatases in autoimmunity. Annu Rev Immunol 2008, 26:29-55.

10. Kung C, Pingel JT, Heikinheimo M, Klemola T, Varkila K, Yoo LI, Vuopala K, Poyhonen M, Uhari M, Rogers M, Speck SH, Chatila T, Thomas ML: Mutations in the tyrosine phosphatase CD45 gene in a child with severe combined immunodeficiency disease. Nat Med 2000, 6:343-345.

11. Tchilian EZ, Wallace DL, Wells RS, Flower DR, Morgan G, Beverley PC: A deletion in the gene encoding the CD45 antigen in a patient with SCID. $\mathrm{J}$ Immunol 2001, 166:1308-1313.

12. Thude H, Hundrieser J, Wonigeit $K$, Schwinzer R: A point mutation in the human CD45 gene associated with defective splicing of exon A. Eur J Immunol 1995, 25:2101-2106.

13. Hermiston $M L, X u Z$, Weiss $A: C D 45$ : a critical regulator of signaling thresholds in immune cells. Annu Rev Immunol 2003, 21:107-137.

14. Gregersen PK, Lee H, Batliwalla F, Begovich AB: PTPN22: Setting thresholds for autoimmunity. Seminars in Immunology 2006, 18:214-223.

15. Begovich AB, Carlton VEH, Honigberg LA, Schrodi SJ, Chokkalingam AP, Alexander HC, Ardlie KG, Huang Q, Smith AM, Spoerke JM, Conn MT, Chang M, Chang SP, Saiki RK, Catanese JJ, Leong DU, Garcia VE, McAllister LB, Jeffery DA, Lee AT, Batliwalla F, Remmers E, Criswell LA, Seldin MF, Kastner DL, Amos Cl, Sninsky JJ, Gregersen PK: A missense single-nucleotide polymorphism in a gene encoding a protein tyrosine phosphatase (PTPN22) is associated with rheumatoid arthritis. Am J Hum Genet 2004, 75:330-7.

16. Orozco G, Sánchez E, González-Gay MA, López-Nevot MA, Torres B, Cáliz R, Ortego-Centeno N, Jiménez-Alonso J, Pascual-Salcedo D, Balsa A, de Pablo R, Nuñez-Roldan A, González-Escribano MF, Martín J: Association of a functional single-nucleotide polymorphism of PTPN22, encoding lymphoid protein phosphatase, with rheumatoid arthritis and systemic lupus erythematosus. Arthritis Rheum 2005, 52:219-24.

17. Chelala C, Duchatelet S, Joffret M, Bergholdt R, Dubois-Laforgue D, Ghandil P, Pociot F, Caillat-Zucman S, Timsit J, Julier C: PTPN22 R620W functional variant in type 1 diabetes and autoimmunity related traits. Diabetes 2007, 56:522-6.

18. Dieudé P, Guedj M, Wipff J, Avouac J, Hachulla E, Diot E, Granel B, Sibilia J, Cabane J, Meyer O, Mouthon L, Kahan A, Boileau C, Allanore Y: The PTPN22 620W allele confers susceptibility to systemic sclerosis: findings of a large case-control study of European Caucasians and a metaanalysis. Arthritis Rheum 2008, 58:2183-8.

19. Vandiedonck C, Capdevielle C, Giraud M, Krumeich S, Jais J, Eymard B, Tranchant C, Gajdos P, Garchon H: Association of the PTPN22*R620W polymorphism with autoimmune myasthenia gravis. Ann Neurol 2006, 59:404-407.

20. Jacobsen M, Schweer D, Ziegler A, Gaber R, Schock S, Schwinzer R, Wonigeit K, Lindert RB, Kantarci O, Schaefer-Klein J, Schipper HI, Oertel WH, Heidenreich F, Weinshenker BG, Sommer N, Hemmer B: A point mutation in PTPRC is associated with the development of multiple sclerosis. Nat Genet 2000, 26:495-9.

21. Hannelius U, Lindgren CM, Melén E, Malmberg A, von Dobeln U, Kere J: Phenylketonuria screening registry as a resource for population genetic studies. J Med Genet 2005, 42:e60.

22. Lefvert AK, Bergström K, Matell G, Osterman PO, Pirskanen R: Determination of acetylcholine receptor antibody in myasthenia gravis: clinical usefulness and pathogenetic implications. I Neurol Neurosurg Psychiatr 1978, 41:394-403. 
23. Jurinke $C$, van den Boom D, Cantor CR, Köster H: Automated genotyping using the DNA MassArray technology. Methods Mol Biol 2002, 187:179-192.

24. Skol AD, Scott $L$, Abecasis GR, Boehnke M: Joint analysis is more efficient than replication-based analysis for two-stage genome-wide association studies. Nat Genet 2006, 38:209-213.

25. Compston DA, Vincent A, Newsom-Davis J, Batchelor JR: Clinical, pathological, HLA antigen and immunological evidence for disease heterogeneity in myasthenia gravis. Brain 1980, 103:579-601.

26. Schwinzer R, Schraven B, Kyas U, Meuer SC, Wonigeit K: Phenotypical and biochemical characterization of a variant CD45R expression pattern in human leukocytes. Eur J Immunol 1992, 22:1095-1098.

27. Ballerini C, Rosati E, Salvetti M, Ristori G, Cannoni S, Biagioli T, Massacesi L, Sorbi S, Vergelli M: Protein tyrosine phosphatase receptor-type $C$ exon 4 gene mutation distribution in an Italian multiple sclerosis population. Neurosci Lett 2002, 328:325-327.

28. Vyshkina T, Leist TP, Shugart YY, Kalman B: CD45 (PTPRC) as a candidate gene in multiple sclerosis. Mult Scler 2004, 10:614-617.

29. Tchilian EZ, Beverley PC: Altered CD45 expression and disease. Trends in Immunology 2006, 27:146-153.

30. Gomez-Lira M, Liguori M, Magnani C, Bonamini D, Salviati A, Leone M, Andreoli V, Trojano M, Valentino P, Savettieri G, Quattrone A, Pignatti PF, Momigliano-Richiardi P, Giordano M: CD45 and multiple sclerosis: the exon 4 C77G polymorphism (additional studies and meta-analysis) and new markers. J Neuroimmunol 2003, 140:216-21.

31. Schwinzer R, Witte T, Hundrieser J, Ehlers S, Momot T, Hunzelmann N, Krieg T, Schmidt RE, Wonigeit K: Enhanced frequency of a PTPRC (CD45) exon A mutation (77C->G) in systemic sclerosis. Genes Immun 2003, 4:168-9.

32. Vogel A, Strassburg CP, Manns MP: 77 C/G mutation in the tyrosine phosphatase CD45 gene and autoimmune hepatitis: evidence for a genetic link. Genes Immun 2003, 4:79-81.

33. Tchilian EZ, Gil J, Navarro ML, Fernandez-Cruz E, Chapel H, Misbah S, Ferry B, Renz H, Schwinzer R, Beverley PCL: Unusual case presentations associated with the CD45 C77G polymorphism. Clin Exp Immunol 2006, 146:448-454.

34. Szvetko AL, Jones A, Mackenzie J, Tajouri L, Csurhes PA, Greer JM, Pender MP, Griffiths LR: An investigation of the C77G and C772T variations within the human protein tyrosine phosphatase receptor type $C$ gene for association with multiple sclerosis in an Australian population. Brain Res 2009, 1255:148-152.

35. Tackenberg B, Nitschke M, Willcox N, Ziegler A, Nessler S, Schumm F, Oertel WH, Hemmer B, Sommer N: CD45 isoform expression in autoimmune myasthenia gravis. Autoimmunity 2003, 36:117-121.

36. Zilch CF, Walker AM, Timón M, Goff LK, Wallace DL, Beverley PC: A point mutation within CD45 exon $A$ is the cause of variant CD45RA splicing in humans. Eur J Immunol 1998, 28:22-29.

37. Barcellos LF, Caillier S, Dragone L, Elder M, Vittinghoff $E$, Bucher $P$, Lincoln RR, Pericak-Vance M, Haines JL, Weiss A, Hauser SL, Oksenberg JR: PTPRC (CD45) is not associated with the development of multiple sclerosis in U.S. patients. Nat Genet 2001, 29:23-4.

38. Vorechovsky I, Kralovicova J, Tchilian E, Masterman T, Zhang Z, Ferry B, Misbah S, Chapel H, Webster D, Hellgren D, Anvret M, Hillert J, Hammarstrom L, Beverley PC: Does 77C->G in PTPRC modify autoimmune disorders linked to the major histocompatibility locus? Nat Genet 2001, 29:22-3.

39. Miterski B, Sindern E, Haupts M, Schimrigk S, Epplen JT: PTPRC (CD45) is not associated with multiple sclerosis in a large cohort of German patients. BMC Med Genet 2002, 3:3

40. Wood JP, Bieda K, Segni M, Herwig J, Krause M, Usadel KH, Badenhoop K: CD45 exon 4 point mutation does not confer susceptibility to type 1 diabetes mellitus or Graves' disease. Eur J Immunogenet 2002, 29:73-4.

41. Nicholas RS, Partridge J, Donn RP, Hawkins C, Boggild MD: The role of the PTPRC (CD45) mutation in the development of multiple sclerosis in the North West region of the United Kingdom. J Neurol Neurosurg Psychiatr 2003, 74:944-945.

42. Thude H, Rosenhahn S, Hunger-Dathe W, Müller U, Barz D: A transmembrane protein-tyrosine phosphatase receptor type $C$ (CD45) exon A point mutation (77 $C$ to $G$ ) is not associated with the development of type 1 diabetes mellitus in a German population. Eur J Immunogenet 2004, 31:245-7.
43. Cocco E, Murru MR, Melis C, Schirru L, Solla E, Lai M, Rolesu M, Marrosu MG PTPRC (CD45) C77G mutation does not contribute to multiple sclerosis susceptibility in Sardinian patients. J Neurol 2004, 251:1085-1088.

44. Esteghamat F, Noorinayer B, Sanati MH, Hekmatdoost A, Zafarghandi M, Shalmani HM, Agah M, Zali MR: C77G mutation in protein tyrosine phosphatase CD45 gene and autoimmune hepatitis. Hepatol Res 2005, 32:154-157.

45. Kirsten H, Blume M, Emmrich F, Hunzelmann N, Mierau R, Rzepka R, Vaith P, Witte T, Melchers I, Ahnert P: No association between systemic sclerosis and C77G polymorphism in the human PTPRC (CD45) gene. J Rheumatol 2008, 35:1817-9.

46. Pan-Hammarström Q, Hammarström L: Antibody deficiency diseases. Eur J Immunol 2008, 38:327-33.

doi:10.1186/1756-0500-3-292

Cite this article as: Ramanujam et al:: The CD45 77C/G allele is not associated with myasthenia gravis - a reassessment of the potential role of CD45 in autoimmunity. BMC Research Notes 2010 3:292.

\section{Submit your next manuscript to BioMed Central and take full advantage of:}

- Convenient online submission

- Thorough peer review

- No space constraints or color figure charges

- Immediate publication on acceptance

- Inclusion in PubMed, CAS, Scopus and Google Scholar

- Research which is freely available for redistribution

Submit your manuscript at www.biomedcentral com/submit
C) Biomed Central 